\title{
EFFECT OF SOWING WINDOWS AND IRRIGATION REGIMES ON APAR AND DRY MATTER OF SUMMER GROUNDNUT IN WESTERN MAHARASHTRA
}

\author{
S.V. Khadtare* and H.N. Aiwale \\ AICRP on Safflower, Krishak Bhawan, ZARS, 97, Raviwar Peth, Solapur. \\ E.mail: khadtareagronomy@gmail.com
}

\begin{abstract}
ABSTRACS:
The field experiment was conducted during summer season of 2014 and 2015 with the objective to develop the relationship between radiation interception and dry matter production in groundnut. The experiment composed of three dates of sowing and four irrigation regimes. Early sowing in $7^{\text {th }} \mathrm{MW}$ and irrigation of $100 \%$ of $\mathrm{CPE}$ through microsprinkler significantly increased absorbed photosynthetically active radiation. The radiation use efficiency showed increasing trend with advancement in crop age up to peg formation, thereafter, it was declined towards physiological maturity. Higher RUE was recorded under $7^{\text {th }}$ MW till peg formation. Higher values of fraction of PAR intercepted were recorded under groundnut sown at MW 7. The crop received higher irrigation showed significantly higher radiation interception. It was in the order of $100 \%$ of $\mathrm{CPE}>80 \%$ of $\mathrm{CPE}>1.0 \mathrm{IW} / \mathrm{CPE}>60 \%$ of $\mathrm{CPE}$.
\end{abstract}

Key words: - Groundnut, sowing windows, microsprinkler, APAR, RUE

\section{INTRODUCTION:}

Groundnut (Arachis hypogaea L.) is one of the prominent and momentous short-day annual legume crop of the world. It is grown on 35.5 mha across 82 countries in the world. It is grown on area of 5.5 mha with a total production of $9.7 \mathrm{mt}$ with productivity of $1.75 \mathrm{t} \mathrm{ha}^{-1}$ in India. While, biological potency of groundnut is estimated to reach $3.0-4.5$ tonha-1 (Anonymous, 2018).

The opportunities to increase peanut production are large under summer season due to ample light and lower infestation of disease and pests. Higher temperature in tropics is likely to influence crop yield negatively while increasing the demand for already limited water supply in our country. Economic yield of a crop comprises of the function of growth rate, duration of growth and proportion of growth realized in the grain component. Peanut, like other plants requires not only adequate water and nutrient but also solar radiation that can effectively improve the yields. Light is one of the major factors for growth and biomass production of groundnut and dry weight (Nautiyal et al.1999). Canopy structure may affect peanut responses to plant population in terms of solar radiation interception and growth of the crop. The total dry weight increases with increasing solar radiation. There was a belief that the conversion efficiency is controlled genetically, but environmental factors and variety, climatic changes, plant arrangement and soil fertility play an important role on photosynthesis. Since water stress brings about changes in growth and dry matter partitioning in groundnut, there is need of efficient and economic use of irrigation water so as to increase the area and productivity of summer groundnut. 
Due to scenario of climate change, an emphasis was made with the objective to develop the relationship between radiation interception and dry matter production in groundnut at Mahatma Phule Krishi Vidyapeeth (MPKV), Rahuri during summer, 2014 and 2015.

\section{MATERIAL AND METHODS:}

The field experiment was conducted for two consecutive years at the farm of Water Management Project, MPKV, Rahuri, during summer season of 2014 and 2015. MPKV, Rahuri lies between $19^{\circ} 48^{\circ} \mathrm{N}$ and $19^{\circ} 57^{\circ} \mathrm{N}$ latitude and 740 32 $\mathrm{E}$ and 740 19' $\mathrm{E}$ longitudes. Climatologically, this area falls in semi-arid tropics with annual rainfall varying from 307 to $619 \mathrm{~mm}$. The annual maximum and minimum temperature ranges between 33 and $43^{\circ} \mathrm{C}$ and 3.0 and $18.0^{\circ} \mathrm{C}$, respectively, while relative humidity during morning and evening hours is 59 to 35 per cent, respectively. The pan evaporation ranges between 5.3 and $12.1 \mathrm{~mm}$ while, the sunshine hours between 7 and 9 days $^{-1}$. Annual bright sunshine hours day ${ }^{-1}$ were 8.0 and 8.8 during 2014 and 2015, respectively.

The experiment composed of three windows of sowing. viz. $\mathrm{D}_{1}$ : $7^{\text {th }}$ Meteorological week (MW), $\mathrm{D}_{2}$ : $9^{\text {th }} \mathrm{MW}$ and $\mathrm{D}_{3}: 11^{\text {th }} \mathrm{MW}$ with four irrigation regimes. viz. $\mathrm{I}_{1}$ : micro-sprinkler irrigation at $60 \%$ of cumulative pan evaporation $(\mathrm{CPE}), \quad \mathrm{I}_{2}$ : micro-sprinkler irrigation at $80 \%$ of $\mathrm{CPE}, \mathrm{I}_{3}$ : micro-sprinkler irrigation at $100 \%$ of $\mathrm{CPE}$ and $\mathrm{I}_{4}$ : surface irrigation at $1.0 \mathrm{IW} / \mathrm{CPE}$ ratio. Cumulative pan evaporation $(\mathrm{CPE})$ is the sum of daily evaporation between two successive irrigations. While, irrigation water (IW) is predetermined depth of irrigation water. The irrigation frequency was twice a week. The growth observations were recorded at the end of physiological growth stage during both the years. The growth stages were $\mathrm{P}_{1}$ : Sowing to germination, $\mathrm{P}_{2}$ : Germination to branching, $\mathrm{P}_{3}$ : Branching to first flower, $\mathrm{P}_{4}$ : First flower to 50 $\%$ flowering, $\mathrm{P}_{5}: 50 \%$ flowering to peg formation, $\mathrm{P}_{6}$ : Peg formation to rapid kernel growth, $\mathrm{P}_{7}$ : Rapid kernel growth to physiological maturity (Varaprasad, 2010). For determining dry matter per plant, one randomly selected plant was washed and all the plant parts,viz. leaves, stem, roots, flower and pods were separated. The parts were sundried and then allow drying in thermostatically controlled hot air oven at $60 \pm$ $2^{\circ} \mathrm{C}$ till constant weight was recorded. The dry matter study was carried out at the end of each growth stage. Radiation measurements were made at each physiological growth stage in each plot at mid noon using line quantum sensor and digital lux meter. Solar radiation from crop canopy and soil was also recorded by inverting the sensor.

\section{Determination of absorbed radiation}

Absorbed PAR was worked out by adopting the equation given by Gallo and Daughtry, 1986.

$$
\mathrm{Ra}=(\mathrm{Ri}+\mathrm{Rs})-(\mathrm{Rt}+\mathrm{Rr})
$$

Where,

$\mathrm{Ra}=$ Absorbed PAR, $\quad \mathrm{Ri}=$ Incident PAR, $\mathrm{Rr}=$ Plant canopy reflected PAR

$$
\mathrm{Rt}=\text { Transmitted PAR, } \mathrm{Rs}=\text { Soil }
$$
surface reflected PAR

$$
\text { To calculate light use }
$$

efficiency, cumulated absorbed PAR was converted from $\mu \mathrm{molm}^{-2} \mathrm{~s}^{-1}$ to $\mathrm{MJm}^{-2}$ by multiplication of factor 0.0188 .

Light interception (LI) and Light interception (\%) was calculated using the formula as given by (Flenet et al., 1996).

$$
\begin{aligned}
& \mathrm{LI}=(\mathrm{Ri}-\mathrm{Rt}) \\
& \mathrm{LI}(\%)=(\mathrm{Ri}-\mathrm{Rt}) /(\mathrm{Ri}) \text { Where, }
\end{aligned}
$$

$\mathrm{LA}=$ Intercepted PAR, $\mathrm{Ri}=$ Incident

PAR, $\quad$ Rt $=$ Transmitted PAR

and radiation use efficiency (RUE) was calculated by using formula, 


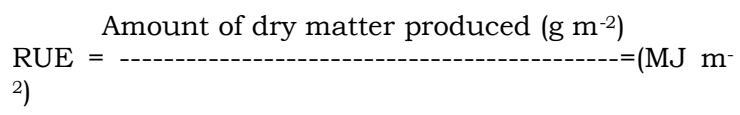

Amount of cumulative PAR absorbed

In order to find out the quantum of I PAR in dry matter production, correlation between radiation interception and dry matter produced under different sowing dates were done by statistical analysis using SPSS 8.0 software.

\section{RESULTS AND DISCUSSION:}

\section{APAR and RUE}

Early sowing in $7^{\text {th }}$ MW had significantly increased absorbed photosynthetically active radiation (PAR) as compared to sowing in $9^{\text {th }}$ and $11^{\text {th }} \mathrm{MW}$ at all the stages of crop growth and it was significantly increased with adequate irrigation of $100 \%$ of $\mathrm{CPE}$ microsprinkler irrigation regime followed by $80 \%$ of CPE, 1.0 IW: CPE surface irrigation and $60 \%$ of CPE micro-sprinkler irrigation regimes at all the days of observations of the experimentation. The interaction was found non-significant at all the crop growth stages. The radiation use efficiency showed increasing trend with advancement in crop age up to peg formation, thereafter, it was declined towards physiological maturity due to senescence of the leaves.

Higher RUE was recorded under $7^{\text {th }} \mathrm{MW}$ sown groundnut and irrigation at $100 \%$ of $\mathrm{CPE}$. The highest PAR and radiation use efficiency were found when crop was sown in $7^{\text {th }}$ MW these might be due to crop sown in proper sowing window and adequate soil moisture conditions results in production of maximum leaf area. A positive linear correlation existed between the intercepted radiation and the dry matter accumulation in the groundnut. Similar results were reported by Haro et al. (2011).
Previous research of Kiniry et al. (2005) showed that, top 42 per cent of the leaf area in a groundnut stand intercepted 74 per cent of the incident light. The contribution of younger leaves (leaves 2 to 6) in absorbing PAR decreases due to wilting and nastic folding during the high period of irradiance under stressed condition and leaf expansion in micro-sprinkler irrigation at $100 \%$ of $\mathrm{CPE}$ remains unchanged even at peak noon hours. This might be the probable reason of high values of APAR under higher frequency irrigation $(100 \%$ of $\mathrm{CPE})$ through microsprinkler.

The highest values of RUE recorded in irrigation treatment of $100 \%$ of CPE through micro-sprinkler was might be due to higher leaf area and biomass production. When LAI is large, maximum light interception moves deeper into the canopy thus, amount of absorbed insol radiation is higher through canopy. The results are in agreement with previous research of Black et al. (1985).

\section{Radiation interception}

Data pertaining to radiation interception during different phenophases has been shown in Table 3. Higher values of fraction of PAR intercepted were recorded under groundnut sown at MW 7. While, MW 11 registered lowest values of I PAR. The per cent values of intercepted PAR with incident PAR showed highest light interception by canopy at $\mathrm{P}_{4}$ to $\mathrm{P}_{6}$. Higher interception under $7^{\text {th }} \mathrm{MW}$ was attributed to higher groundcover due to increased leaf area.

Radiation interception as influenced due to various irrigation regimes showed that crop received higher irrigation showed significantly higher radiation interception. It was in the order of $100 \%$ of $\mathrm{CPE}>80 \%$ of $\mathrm{CPE}>1.0$ $\mathrm{IW} / \mathrm{CPE}>60 \%$ of $\mathrm{CPE}$, pointed out that optimum irrigation is resulted in 
comparatively higher light interception. The per cent values of I PAR under $100 \%$ of CPE showed that, at the end of P4, P5 and P6 phenophases, intercepted PAR accounted to the tune of $76.6,88.6$ and 86.6 per cent of APAR.

\section{Correlation analysis}

\section{Correlation between dry matter production and radiation}

It is well understood the role of temperature and bright sunshine in different plant physiological processes. However, least information on role of incident and intercepted PAR in dry matter accumulation in groundnut is available. Hence, an attempt is made in order to quantify the relationship between stagewise resultant total dry matter accumulation per plant and incident PAR (incident PAR above canopy- PAR below canopy) during different sowing windows.

It was observed that from the data presented in Table 4, absorbed and incident PAR had positive relationship with dry matter production at each stage under all sowing windows. While, significantly positive association was noticed from branching to rapid kernel growth under crop sown during MW 7. The magnitude of relationship (r) was recorded higher at MW 7> MW 9> MW 11 at each growth stage during both the years of experimentation. Dry matter produced under midlate (MW 9) and late sown (MW 11) groundnut exhibited non-significant relationship at rapid kernel growth and physiological maturity.

\section{REFERENCES:}

Anonymous. 2018. Economic survey 2014-15, statistical appendix. Available at www.indiabudget.nic.in /es2014-15/estat.1.pdf

Black, C.R., Tang, D.Y. and Ong, C.K. 1985. Effect of moisture stress on the water relations and water use of groundnut stands. New physiologist. 100: 313- 328

Flenet, F., Kiniry, J.E., Board, J.E., Westgate, M.E.,Reicosky, D.C. 1996. Row spacing effects on light extinction coefficients of corn, sorghum, soybean, and sunflower. Agron. J. 88: 185190.

Gallo, P. and Daughtry, C.S.T. 1986. Technique for measuring interception and absorbed photosynthatically active radiation in corn canopies. Agron. J. 78:752-756.

Haro, R.J., Mantese, A. and Otegui, M.E. 2011. Peg viability and pod set in peanut: Response to impaired pegging and water deficit. Flora. 206 (10): 865871.

Kiniry, J. R., Simpson, C. E., Schubert, A. M. and Reed, J. D. 2005. Peanut leaf area index, light interception, radiation use efficiency and harvest index at three sites in Texas. Field Crops Res. 91: 297-306.

Varaprasad, P.V., Kakani, V.G. and Upadhyaya, H.D. 2010. Growth and production of groundnut. In: Soils, plant growth and crop production. Vol. 2. Encyclopaedia of Life Support System.

Nautiyal, P.C., Ravindra, V. and Joshi, Y.C. 1999. Net photosynthetic rate in peanut (Arachis hypogaea L.): Influence of leaf position, time of day and reproductive sink. Photosynthetica, 36: 129-138. 
Table-1. Effect of sowing dates and irrigation regimes on APAR (micro mol. $\mathbf{m}^{-2} \mathbf{s}^{-1}$ ) of groundnut

\begin{tabular}{|c|c|c|c|c|c|c|c|}
\hline \multirow[t]{2}{*}{ Treatments } & \multicolumn{7}{|c|}{ Absorbed photosynthetically active radiation (micro mol. $\mathrm{m}^{-2} \mathrm{~s}^{-1}$ ) } \\
\hline & $\mathrm{P}_{1}$ & $\mathrm{P}_{2}$ & $\mathrm{P}_{3}$ & $\mathrm{P}_{4}$ & $\mathrm{P}_{5}$ & $\mathrm{P}_{6}$ & $\mathrm{P}_{7}$ \\
\hline \multicolumn{8}{|l|}{ Sowing dates } \\
\hline $7^{\text {th }}$ MW (12-18 Feb) & 8.5 & 202 & 350 & 664 & 781 & 697 & 527 \\
\hline $9^{\text {th }}$ MW (26 Feb-04 Mar) & 7.5 & 173 & 322 & 606 & 685 & 633 & 498 \\
\hline $11^{\text {th }}$ MW (12-18 Mar) & 8.5 & 158 & 285 & 563 & 642 & 582 & 458 \\
\hline SE.m \pm & 1.03 & 5.8 & 6.1 & 6.9 & 6.9 & 10.4 & 8.2 \\
\hline $\mathrm{CD}(0.05 \%)$ & $\mathrm{NS}$ & 18.4 & 19.0 & 21.5 & 21.3 & 31.3 & 24.8 \\
\hline \multicolumn{8}{|l|}{ Irrigation regimes } \\
\hline $60 \%$ of CPE & 9 & 151 & 260 & 551 & 646 & 585 & 446 \\
\hline $80 \%$ of CPE & 8 & 186 & 344 & 626 & 725 & 659 & 507 \\
\hline $100 \%$ of CPE & 9 & 205 & 364 & 672 & 758 & 695 & 540 \\
\hline 1.0 IW/CPE (Surface) & 9 & 172 & 312 & 595 & 683 & 611 & 485 \\
\hline SE.m + & 0.8 & 7.6 & 7.2 & 5.6 & 5.6 & 9.2 & 3.7 \\
\hline $\mathrm{CD}(0.05 \%)$ & $\mathrm{NS}$ & 22.9 & 21.8 & 17.0 & 16.9 & 27.5 & 11.1 \\
\hline \multicolumn{8}{|l|}{ Interaction } \\
\hline SE.m \pm & 2.3 & 17.7 & 24.0 & 32.9 & 47.5 & 43.3 & 30.1 \\
\hline CD $(0.05 \%)$ & $\mathrm{NS}$ & NS & NS & $\mathrm{NS}$ & $\mathrm{NS}$ & NS & NS \\
\hline
\end{tabular}

Table-2. Effect of sowing dates and irrigation regimes on radiation use efficiency $\left(\mathrm{g} \mathrm{MJ}^{-1}\right)$ of groundnut

\begin{tabular}{|c|c|c|c|c|c|c|c|}
\hline \multirow[t]{2}{*}{ Treatments } & \multicolumn{7}{|c|}{ Radiation use efficiency $\left(\mathrm{g} \mathrm{MJ}^{-1}\right)$} \\
\hline & $\mathrm{P}_{1}$ & $\mathrm{P}_{2}$ & $\mathrm{P}_{3}$ & $\mathrm{P}_{4}$ & $\mathrm{P}_{5}$ & $\mathrm{P}_{6}$ & $\mathrm{P}_{7}$ \\
\hline \multicolumn{8}{|l|}{ Sowing dates } \\
\hline $7^{\text {th }}$ MW (12-18 Feb) & 0.05 & 0.81 & 1.03 & 1.22 & 1.42 & 1.11 & 0.53 \\
\hline $9^{\text {th }}$ MW (26 Feb-04 Mar) & 0.05 & 0.71 & 0.94 & 1.10 & 1.33 & 1.00 & 0.42 \\
\hline $11^{\text {th }}$ MW (12-18 Mar) & 0.05 & 0.65 & 0.83 & 1.05 & 1.23 & 0.91 & 0.35 \\
\hline SE.m \pm & 0.05 & 0.08 & 0.06 & 0.03 & 0.04 & 0.06 & 0.05 \\
\hline $\mathrm{CD}(0.05 \%)$ & NS & $\mathrm{NS}$ & 0.13 & 0.10 & 0.14 & 0.17 & 0.14 \\
\hline \multicolumn{8}{|l|}{ Irrigation regimes } \\
\hline $60 \%$ of $\mathrm{CPE}$ & 0.05 & 0.65 & 0.80 & 0.95 & 1.13 & 0.85 & 0.30 \\
\hline $80 \%$ of CPE & 0.06 & 0.74 & 0.99 & 1.20 & 1.35 & 1.06 & 0.47 \\
\hline $100 \%$ of CPE & 0.05 & 0.78 & 1.06 & 1.30 & 1.61 & 1.20 & 0.55 \\
\hline 1.0 IW/CPE (Surface) & 0.05 & 0.73 & 0.88 & 1.04 & 1.19 & 0.92 & 0.40 \\
\hline SE.m \pm & 0.04 & 0.06 & 0.07 & 0.05 & 0.11 & 0.07 & 0.04 \\
\hline $\mathrm{CD}(0.05 \%)$ & $\mathrm{NS}$ & $\mathrm{NS}$ & 0.13 & 0.17 & 0.34 & 0.22 & 0.13 \\
\hline \multicolumn{8}{|l|}{ Interaction } \\
\hline SE.m \pm & 0.05 & 0.14 & 0.10 & 0.13 & 0.19 & 0.30 & 0.12 \\
\hline $\mathrm{CD}(0.05 \%)$ & NS & $\mathrm{NS}$ & $\mathrm{NS}$ & $\mathrm{NS}$ & NS & $\mathrm{NS}$ & $\mathrm{NS}$ \\
\hline
\end{tabular}


I J R B A T, Issue (VIII), Vol. III, Sept 2020: 77-83

e-ISSN $2347-517 X$

Table-3. Effect of sowing dates and irrigation regimes on radiation interception (micro mol. $\mathrm{m}^{-2}$ ) of groundnut

\begin{tabular}{|c|c|c|c|c|c|c|c|}
\hline \multirow[t]{2}{*}{ Treatments } & \multicolumn{7}{|c|}{ Radiation interception (micro mol. $\mathrm{m}^{-2}$ ) } \\
\hline & $\mathrm{P}_{1}$ & $\mathrm{P}_{2}$ & $\mathrm{P}_{3}$ & $\mathrm{P}_{4}$ & $\mathrm{P}_{5}$ & $\mathrm{P}_{6}$ & $\mathrm{P}_{7}$ \\
\hline \multicolumn{8}{|l|}{ Sowing dates } \\
\hline $7^{\text {th }}$ MW (12-18 Feb) & $\begin{array}{l}25 \\
(3)\end{array}$ & $\begin{array}{l}279.5 \\
(23.2)\end{array}$ & $\begin{array}{c}508 \\
(47.1)\end{array}$ & $\begin{array}{l}754.5 \\
(75.1)\end{array}$ & $\begin{array}{c}894 \\
(86.8)\end{array}$ & $\begin{array}{l}801.5 \\
(80.7)\end{array}$ & $\begin{array}{l}601.5 \\
(63.2)\end{array}$ \\
\hline $9^{\text {th }}$ MW (26 Feb-04 Mar) & $\begin{array}{l}25.5 \\
(3.1)\end{array}$ & $\begin{array}{l}245.5 \\
(21.8)\end{array}$ & $\begin{array}{c}420 \\
(38.1)\end{array}$ & $\begin{array}{c}609 \\
(68.8)\end{array}$ & $\begin{array}{l}701.5 \\
(76.6)\end{array}$ & $\begin{array}{l}627.5 \\
(71.7)\end{array}$ & $\begin{array}{l}430.5 \\
(56.4)\end{array}$ \\
\hline $11^{\text {th }}$ MW (12-18 Mar) & $\begin{array}{c}28 \\
(3.3)\end{array}$ & $\begin{array}{c}211 \\
(19.9)\end{array}$ & $\begin{array}{l}349.5 \\
(26.3)\end{array}$ & $\begin{array}{c}506 \\
(56.4)\end{array}$ & $\begin{array}{l}606.5 \\
(65.4)\end{array}$ & $\begin{array}{l}566.5 \\
(61.1)\end{array}$ & $\begin{array}{l}370.5 \\
(48.6)\end{array}$ \\
\hline SE.m \pm & 3.5 & 16.2 & 37.15 & 59.8 & 72.8 & 53.85 & 43.5 \\
\hline $\mathrm{CD}(0.05 \%)$ & $\mathrm{NS}$ & 48.5 & 111.5 & 179.5 & 218.5 & 161.5 & 130.5 \\
\hline \multicolumn{8}{|l|}{ Irrigation regimes } \\
\hline $60 \%$ of $\mathrm{CPE}$ & $\begin{array}{l}26.5 \\
(3.1)\end{array}$ & $\begin{array}{c}205 \\
(19.7)\end{array}$ & $\begin{array}{l}345.5 \\
(28.2)\end{array}$ & $\begin{array}{l}545.5 \\
(57.5)\end{array}$ & $\begin{array}{l}644.5 \\
(64.6)\end{array}$ & $\begin{array}{c}579 \\
(59.9)\end{array}$ & $\begin{array}{l}364.5 \\
(44.1)\end{array}$ \\
\hline $80 \%$ of $\mathrm{CPE}$ & $\begin{array}{c}23 \\
(3.1)\end{array}$ & $\begin{array}{c}248 \\
(22.4)\end{array}$ & $\begin{array}{l}439.5 \\
(39.5)\end{array}$ & $\begin{array}{l}645.5 \\
(69.4)\end{array}$ & $\begin{array}{c}740 \\
(79.9)\end{array}$ & $\begin{array}{c}670 \\
(71.8)\end{array}$ & $\begin{array}{c}516 \\
(59.9)\end{array}$ \\
\hline $100 \%$ of $\mathrm{CPE}$ & $\begin{array}{l}27.5 \\
(3.1)\end{array}$ & $\begin{array}{l}301.5 \\
(24.3)\end{array}$ & $\begin{array}{l}522.5 \\
(43.6)\end{array}$ & $\begin{array}{c}719 \\
(76.6)\end{array}$ & $\begin{array}{c}854 \\
(88.6)\end{array}$ & $\begin{array}{c}789 \\
(86.6)\end{array}$ & $\begin{array}{c}559 \\
(68.7)\end{array}$ \\
\hline 1.0 IW/CPE (Surface) & $\begin{array}{r}28.5 \\
(3.2) \\
\end{array}$ & $\begin{array}{c}225 \\
(20.2)\end{array}$ & $\begin{array}{c}396 \\
(34.6) \\
\end{array}$ & $\begin{array}{c}584 \\
(63.7) \\
\end{array}$ & $\begin{array}{r}697.5 \\
(72.1) \\
\end{array}$ & $\begin{array}{c}623 \\
(66.4) \\
\end{array}$ & $\begin{array}{l}430.5 \\
(51.4) \\
\end{array}$ \\
\hline SE.m \pm & 3.1 & 22.7 & 34.85 & 34.6 & 47.3 & 43.6 & 19.9 \\
\hline $\mathrm{CD}(0.05 \%)$ & NS & 68 & 104.6 & 103.8 & 141.9 & 130.7 & 59.5 \\
\hline \multicolumn{8}{|l|}{ Interaction } \\
\hline SE.m + & 4.5 & 23.2 & 43 & 69.4 & 93.7 & 75.8 & 50.1 \\
\hline $\mathrm{CD}(0.05 \%)$ & NS & NS & NS & NS & NS & NS & NS \\
\hline
\end{tabular}

Table-4. Correlation coefficient between stagewise dry matter and APAR and radiation interception (micro $\mathbf{~ m o l ~ m}^{-2}$ )

\begin{tabular}{|c|c|c|c|c|c|c|c|c|c|c|c|c|c|c|}
\hline \multirow{4}{*}{\begin{tabular}{|l|} 
Treatments \\
Sowing \\
dates
\end{tabular}} & \multicolumn{14}{|c|}{ Correlation between dry matter $\left(\mathrm{g} \mathrm{plant}^{-1}\right)$ and I PAR and A PAR (micro mol. $\left.\mathrm{m}^{-2}\right)$} \\
\hline & \multicolumn{14}{|c|}{2014} \\
\hline & \multicolumn{2}{|c|}{$\mathrm{P}_{1}$} & \multicolumn{2}{|c|}{$\mathrm{P}_{2}$} & \multicolumn{2}{|c|}{$\mathrm{P}_{3}$} & \multicolumn{2}{|c|}{$\mathrm{P}_{4}$} & \multicolumn{2}{|c|}{$\mathrm{P}_{5}$} & \multicolumn{2}{|c|}{$\mathrm{P}_{6}$} & \multicolumn{2}{|c|}{$\mathrm{P}_{7}$} \\
\hline & A PAR & I PAR & A PAR & I PAR & A PAR & I PAR & A PAR & I PAR & A PAR & I PAR & A PAR & I PAR & A PAR & I PAR \\
\hline $7^{\text {th }} \mathrm{MW}$ & 0.468 & 0.351 & $0.783^{*}$ & $0.682 *$ & $0.811^{*}$ & $0.723^{*}$ & $0.819^{* *}$ & $0.742 *$ & $0.823 * *$ & $0.702 *$ & $0.623^{*}$ & $0.641 *$ & 0.433 & 0.315 \\
\hline $9^{\text {th }} \mathrm{MW}$ & 0.416 & 0.271 & $0.742 *$ & $0.647^{*}$ & 0.773* & $0.671 *$ & $0.781^{*}$ & $0.703^{*}$ & $0.789^{*}$ & $0.631^{*}$ & $0.511^{*}$ & 0.473 & 0.312 & 0.267 \\
\hline \multirow[t]{2}{*}{$11^{\text {th }} \mathrm{MW}$} & 0.392 & 0.232 & $0.698^{*}$ & 0.601* & 0.709* & $0.632^{*}$ & $0.723^{*}$ & 0.658* & 0.742* & $0.578^{*}$ & 0.467 & 0.332 & 0.296 & 0.231 \\
\hline & \multicolumn{14}{|c|}{2015} \\
\hline $7^{\text {th }} \mathrm{MW}$ & 0.491 & 0.366 & $0.823^{*}$ & $0.716^{*}$ & $0.846^{*}$ & $0.732 *$ & $0.854 *$ & $0.749^{*}$ & $0.879 * *$ & $0.771 *$ & $0.719 *$ & $0.623^{*}$ & 0.431 & 0.416 \\
\hline $9^{\text {th }}$ MW & 0.441 & 0.316 & $0.754 *$ & $0.631 *$ & $0.761^{*}$ & $0.654 *$ & $0.792 *$ & $0.688^{*}$ & $0.806^{* *}$ & $0.732 *$ & $0.632 *$ & $0.532 *$ & 0.374 & 0.396 \\
\hline $11^{\text {th }} \mathrm{MW}$ & 0.302 & 0.219 & $0.687^{*}$ & $0.603^{*}$ & $0.713^{*}$ & 0.614 & $0.729^{*}$ & $0.651^{*}$ & $0.756^{*}$ & $0.682 *$ & $0.579 *$ & 0.399 & 0.263 & 0.307 \\
\hline
\end{tabular}

$\mathrm{P}_{1}$ :Sowing to germination

$\mathrm{P}_{4}$ : First flower to $50 \%$ flowering

$\mathrm{P}_{7}$ : Rapid kernel growth to physiological maturity

* Significant at 0.05

*A PAR- Absorbed PAR

*I PAR- Intercepted PAR
$\mathrm{P}_{3}$ : Branching to first flower

$\mathrm{P}_{6}$ : Peg formation to rapid kernel growth
$\mathrm{P}_{2}$ : Germination to branching

$\mathrm{P}_{5}: 50 \%$ flowering to peg formation

** Significant at 0.01 